\title{
Aborto en Chile: un tema sobre el cual es más fácil escribir que hablar
}

\section{Gloria Salazar ${ }^{1}$}

Escribir sobre el aborto es en Chile mucho más fácil que hablar públicamente sobre el mismo tema. Quienes han escrito en este corpus han podido expresar experiencias y opiniones que difícilmente alcanzan las mesas de conversación, salvo en encuentros especialmente programados para abordar esta experiencia de vida ¡tan habitual! que solo es posible en el cuerpo de las mujeres. Olga Grau ha señalado que es un tema del que no se habla, que queda en "una zona oscura y silente". Lo percibo de la misma manera: es un tema que va a dar al lugar en que se guarda lo inconfesable; ése es el sitio al que relegamos una experiencia humana que aunque es muy común entre las mujeres, es hoy fuertemente sancionada por la sociedad y legalmente castigada en nuestro país.

Las mujeres que han entregado su testimonio han sido valientes al rememorar sus experiencias, en las que predominó la desazón de quienes viven una situación que no deseaban. En el caso de quienes abortaron en Chile o en un país donde el aborto está o estaba penalizado, el miedo fue la tónica. ¡Qué diferente la experiencia de la mujer que nos relata su aborto en un país donde esta intervención era legal! Si bien el embarazo fue vivido también por ella como algo no deseado, el contexto en que tuvo esa experiencia fue muy diferente: su decisión personal fue reconocida como lo que es y debería ser siempre, un derecho; recibió consejería psicológica y cuidados clínicos adecuados, en fin, jel ejercicio de una ciudadanía de primera clase!

Los testimonios nos muestran también que la reflexión compartida sobre las experiencias de aborto propias o de nuestras amigas, hermanas y otras mujeres a quienes percibimos como nuestras iguales, nos ayudan a entender las causas, los procesos y a elaborar las emociones que nos provocan. Así también, los 
testimonios nos revelan que el silencio y los intentos de olvido no acallan la experiencia, no contribuyen a entenderla sino que hacen perdurar la culpa y la angustia. Hablar libera, nos hace comprender más profundamente las vivencias, los deseos y no deseos y las eventuales proyecciones de maternidad. La legislación chilena actual impide este proceso de sanación.

¿Qué ha pasado en Chile, el país convivió hasta 1989 con una ley que permitía el aborto terapéutico? Pese a la ilegitimidad del cambio en la legislación, ocurrido durante la dictadura -cuando el poder legislativo lo constituían algunos militares a los que nadie había escogido libremente- una parte de la sociedad chilena ha asumido ese cambio como si nunca hubiese existido una medida distinta. Ciertas instancias sociales -como algunos medios de comunicación- han llegado a constituirse públicamente en entidades controladoras, castigadoras y temerosas de las opciones de las mujeres, decisiones que en el caso del aborto se expresan sobre sus cuerpos y sobre su futuro.

Una parte de la sociedad chilena parece temer a la idea del aborto como a algo que podría generalizarse si se despenalizara, e incluso a veces pareciera que lo teme con efecto retroactivo, como si la eventual permisividad de su ocurrencia hubiese podido afectarle personalmente. Me pregunto si allí hay miedo al abandono o al rechazo familiar, un miedo que persiste desde la infancia y que se expresa en una cerrada negativa a legislar sobre el tema.

Los interesantes aportes de Antonio Bascuñán aluden a las desigualdades de género, señalando el rol que las políticas públicas deben jugar para aminorar los efectos de estas desigualdades. Lo relevante es el papel que en su raciocinio da a la voluntad de la mujer. $Y$ ese es el tema de fondo: la sociedad debe reconocer a las mujeres como ciudadanas de igual categoría que los hombres, cuyos deseos y voluntades tienen el mismo valor que los de los varones.

\section{Nota}

1 Sicóloga. 